\title{
Revision of the Absolute Configuration at C(23) of Lanostanoids and Isolation of Secondary Metabolites from Formosan Soft Coral Nephthea erecta
}

\author{
by Shi-Yie Chenga ${ }^{\mathrm{a}}$, Zhi-Hong Wen ${ }^{\mathrm{a}}$ ), Shang-Kewi Wang ${ }^{\mathrm{b}}$ ), Michael Y. Chiang ${ }^{\mathrm{c}}$ ), \\ Ali A. H. El-Gamal ${ }^{a}{ }^{d}$ ), Chang-Feng Dai ${ }^{e}$ ), and Chang-Yih Duh*a ${ }^{f}$ ) \\ a) Department of Marine Biotechnology and Resources, National Sun Yat-sen University, \\ Kaohsiung 804, Taiwan \\ (phone: 886-7-5252000, ext. 5036; fax: 886-7-5255020; e-mail: yihduh@nsysu.edu.tw) \\ b) Department of Microbiology, Kaohsiung Medical University, Kaohsiung 807, Taiwan \\ c) Department of Chemistry, National Sun Yat-sen University, Kaohsiung 804, Taiwan \\ d) Faculty of Pharmacy, Mansoura University, Egypt \\ e) Institute of Oceanography, National Taiwan University, Taipei, Taiwan \\ ${ }^{\text {f) }}$ Center of Asia-Pacific Marine Researches, National Sun Yat-sen University, Kaohsiung, Taiwan
}

\begin{abstract}
Three new oxygenated ergostanoids, 1-3, one known ergostanoid, 4, one new trinoreudesmadienone, $\mathbf{5}$, one new calamenene type sesquiterpene, $\mathbf{6}$, and one known aristolane-type sesquiterpene, (-)aristolone (7), have been isolated from the AcOEt extract of the soft coral Nephthea erecta. The structures of these compounds were determined by extensive spectroscopic and X-ray crystallographic analysis, as well as Mosher's method. We revised the absolute configuration at $\mathrm{C}(23)$ in the side chain of some lanostanoids as a result of the Mosher's products of $\mathbf{1}$ (i.e., $\mathbf{1 a}$ and $\mathbf{1 b}$ ). The cytotoxicities against selected cancer cells and the anti-inflammatory effects of these tested metabolites $\mathbf{1}-\mathbf{7}$ were determined in vitro.
\end{abstract}

Introduction. - Soft corals belonging to the genus Nephthea have been found to be a rich source of terpenoids and steroids [1-13]. A number of terpenoids have shown an array of biological activities such as insecticidal [12] and cytotoxic activities [5] [7][13]. Earlier studies of marine soft corals have led to the isolation of steroids, some of which have shown cytotoxic [6] and anti-inflammatory activities [14a]. In the course of our ongoing search to explore bioactive substances from marine resources, chromatographic separation of the AcOEt extracts from the soft coral $N$. erecta led to the isolation of three new oxygenated ergostanoids, 1-3, one known ergostanoid, 4, [14b], one new trinoreudesmadienone, $\mathbf{5}$, one new calamenene type sesquiterpene, $\mathbf{6}$, and one known aristolane type sesquiterpene, (-)-aristolone (7) [15]. We describe here the isolation, structural elucidation, cytotoxicity, and anti-inflammatory activity of these metabolites. In addition, we revised the absolute configuration at $\mathrm{C}(23)$ in the side chain of some lanostanoids isolated from the bark and leaves of Amentotaxus formosana [16][17] by using a modified Mosher's method [18][19] for $\mathbf{1}$.

Results and Discussion. - (3 $\beta, 23 S)$-Ergosta-5,24(28)-diene-3,23-diol (1) was isolated as a white amorphous powder. HR-ESI-MS of $\mathbf{1}$ exhibited a pseudo-molecular ion peak at $\mathrm{m} / z 437.3392\left([M+\mathrm{Na}]^{+}\right.$; calc. for 437.3395) and established a molecular 


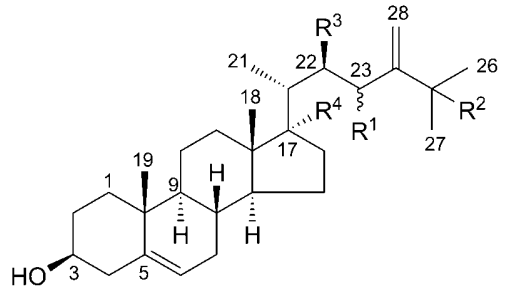

$1 \mathrm{R}^{1}=(S)-\mathrm{OH}, \mathrm{R}^{2}=\mathrm{H}, \mathrm{R}^{3}=\mathrm{H}, \mathrm{R}^{4}=\mathrm{H}$ $2 \mathrm{R}^{1}=(R)-\mathrm{OH}, \mathrm{R}^{2}=\mathrm{H}, \mathrm{R}^{3}=\mathrm{H}, \mathrm{R}^{4}=\mathrm{H}$ $3 \mathrm{R}^{1}=\mathrm{H}, \mathrm{R}^{2}=\mathrm{H}, \mathrm{R}^{3}=\mathrm{OH}, \mathrm{R}^{4}=\mathrm{OH}$ $4 \mathrm{R}^{1}=\mathrm{H}, \mathrm{R}^{2}=\mathrm{OH}, \mathrm{R}^{3}=\mathrm{H}, \mathrm{R}^{4}=\mathrm{H}$<smiles>C[C@@H]1CCC[C@@]2(O)C=CC(=O)C=C12</smiles>

5

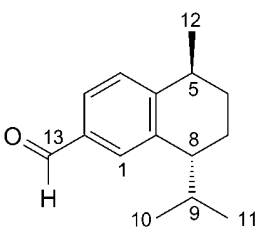

6<smiles>C[C@H]1CCCC2=CC(=O)[C@H]3[C@@H](C)C3(C)[C@H]21</smiles>

7

formula of $\mathrm{C}_{28} \mathrm{H}_{46} \mathrm{O}_{2}$, indicating six degrees of unsaturation. The ${ }^{13} \mathrm{C}-\mathrm{NMR}$ and DEPT spectra displayed 28 signals, including those of five $\mathrm{Me}$, ten $\mathrm{CH}_{2}$, nine $\mathrm{CH}$ groups, and four quaternary C-atoms. ${ }^{1} \mathrm{H}-\mathrm{NMR}$ Signals $(\delta(\mathrm{H}) 4.20(t, J=6.7,1 \mathrm{H})$ and $3.49-3.56$ $(m, 1 \mathrm{H}))($ Table 1$)$ and an IR absorption at $3323 \mathrm{~cm}^{-1}$, together with the observation of two O-bearing C-atom resonances $(\delta(C) 74.4$ and 71.8$)$ in ${ }^{13} \mathrm{C}-\mathrm{NMR}$ spectrum (Table 1), revealed the presence of two $\mathrm{OH}$ groups. Furthermore, a trisubstituted $\mathrm{C}=\mathrm{C}$ bond $(\delta(\mathrm{C}) 121.6$ and 140.7) and a terminal $\mathrm{C}=\mathrm{C}$ bond $(\delta(\mathrm{C}) 108.1$ and 159.2) were assigned on the basis of ${ }^{13} \mathrm{C}-\mathrm{NMR}$ and DEPT spectra of $\mathbf{1}$. The above functionalities accounted for two of the six degrees of unsaturation of $\mathbf{1}$, which possesses a tetracyclic skeleton. The structure of $\mathbf{1}$ was established by extensive $2 \mathrm{D}-\mathrm{NMR}$ analysis $\left({ }^{1} \mathrm{H},{ }^{1} \mathrm{H}-\right.$ COSY, HMQC, and HMBC). Interpretation of the ${ }^{1} \mathrm{H},{ }_{1}^{1} \mathrm{H}-\mathrm{COSY}$ spectrum led to partial structures I, II, and III ( Fig. 1). Partial structures I and II were connected, on the
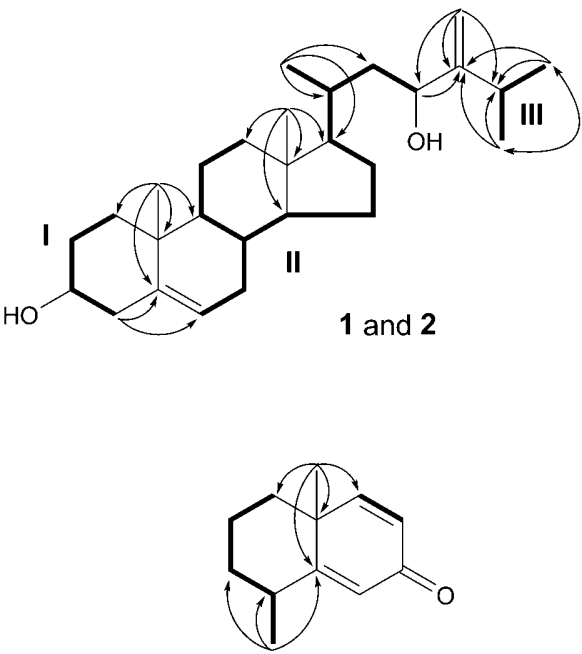

5
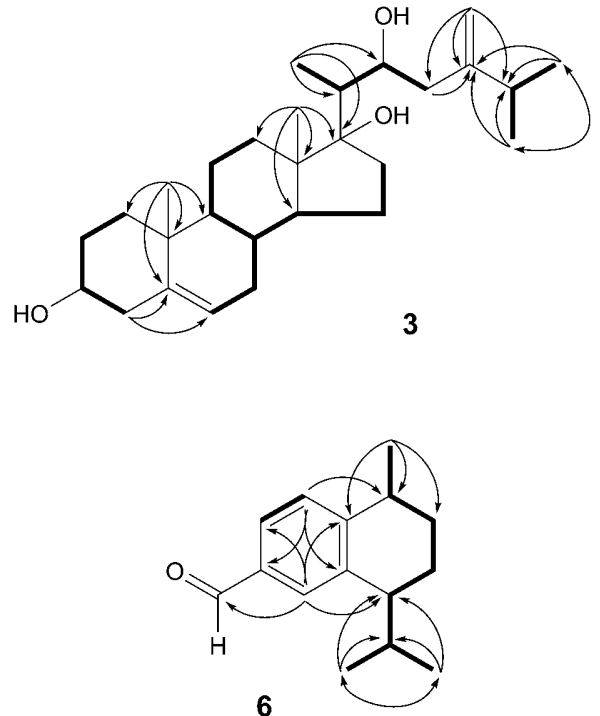

Fig. 1. Key ${ }^{1} \mathrm{H},{ }^{1} \mathrm{H}-\mathrm{COSY}(-)$ and $\mathrm{HMBC}$ correlations $(\mathrm{H} \rightarrow \mathrm{C})$ of $\mathbf{1}-\mathbf{3}, \mathbf{5}$, and $\mathbf{6}$ 
Table $1 .{ }^{1} H$ - and ${ }^{13} C$-NMR Data of Compounds 1-3. $\delta$ in ppm, $J$ in Hz.

\begin{tabular}{|c|c|c|c|c|c|c|}
\hline \multirow[t]{2}{*}{ Position } & \multicolumn{2}{|l|}{$\left.\mathbf{1}^{\mathrm{a}}\right)$} & \multicolumn{2}{|l|}{$\left.\mathbf{2}^{\mathrm{a}}\right)$} & \multicolumn{2}{|l|}{$\left.\mathbf{3}^{\mathrm{b}}\right)$} \\
\hline & $\delta(\mathrm{C})$ & $\delta(\mathrm{H})$ & $\delta(\mathrm{C})$ & $\delta(\mathrm{H})$ & $\delta(\mathrm{C})$ & $\delta(\mathrm{H})$ \\
\hline 1 & $37.2(t)$ & $\begin{array}{l}1.04-1.14\left(m, \mathrm{H}_{\alpha}\right), \\
1.82-1.92\left(m, \mathrm{H}_{\beta}\right)\end{array}$ & $37.2(t)$ & $\begin{array}{l}1.04-1.14\left(m, \mathrm{H}_{\alpha}\right), \\
1.82-1.92\left(m, \mathrm{H}_{\beta}\right)\end{array}$ & $37.2(t)$ & $\begin{array}{l}1.04-1.14\left(m, \mathrm{H}_{\alpha}\right), \\
1.81-1.88\left(m, \mathrm{H}_{\beta}\right)\end{array}$ \\
\hline 2 & $31.6(t)$ & $\begin{array}{l}1.79-1.89\left(m, \mathrm{H}_{\alpha}\right), \\
1.38-1.48\left(m, \mathrm{H}_{\beta}\right)\end{array}$ & $31.6(t)$ & $\begin{array}{l}1.81-1.91\left(m, \mathrm{H}_{\alpha}\right), \\
1.37-1.47\left(m, \mathrm{H}_{\beta}\right)\end{array}$ & $31.6(t)$ & $\begin{array}{l}1.80-1.87\left(m, \mathrm{H}_{\alpha}\right) \\
1.46-1.54\left(m, \mathrm{H}_{\beta}\right)\end{array}$ \\
\hline 3 & $71.8(d)$ & $3.49-3.56(\mathrm{~m})$ & $71.8(d)$ & $3.49-3.56(\mathrm{~m})$ & $71.7(d)$ & $3.51-3.57(\mathrm{~m})$ \\
\hline 4 & $42.2(t)$ & $\begin{array}{l}2.26-2.34\left(m, \mathrm{H}_{\alpha}\right), \\
2.19-2.26\left(m, \mathrm{H}_{\beta}\right)\end{array}$ & $42.3(t)$ & $\begin{array}{l}2.26-2.34\left(m, \mathrm{H}_{\alpha}\right), \\
2.19-2.26\left(m, \mathrm{H}_{\beta}\right)\end{array}$ & $42.2(t)$ & $\begin{array}{l}2.26-2.33\left(m, \mathrm{H}_{\alpha}\right) \\
2.19-2.26\left(m, \mathrm{H}_{\beta}\right)\end{array}$ \\
\hline 5 & $140.7(s)$ & & $140.7(s)$ & & $140.6(s)$ & \\
\hline 6 & $121.6(d)$ & $5.35($ br. $d, J=4.9)$ & $121.7(d)$ & $5.35($ br. $d, J=4.5)$ & $121.6(d)$ & $5.36($ br. $d, J=5.0)$ \\
\hline 7 & $31.8(t)$ & $\begin{array}{l}1.55-1.64\left(m, \mathrm{H}_{\alpha}\right) \\
1.93-2.05\left(m, \mathrm{H}_{\beta}\right)\end{array}$ & $31.9(t)$ & $\begin{array}{l}1.59-1.68\left(m, \mathrm{H}_{\alpha}\right) \\
1.95-2.07\left(m, \mathrm{H}_{\beta}\right)\end{array}$ & $31.8(t)$ & $\begin{array}{l}1.56-1.65\left(m, \mathrm{H}_{\alpha}\right) \\
1.94-2.03\left(m, \mathrm{H}_{\beta}\right)\end{array}$ \\
\hline 8 & $31.8(d)$ & $1.47-1.54(\mathrm{~m})$ & $31.9(d)$ & $1.48-1.55(\mathrm{~m})$ & $32.3(d)$ & $1.45-1.52(\mathrm{~m})$ \\
\hline 9 & $50.0(d)$ & $0.86-1.00(\mathrm{~m})$ & $50.1(d)$ & $0.90-1.04(\mathrm{~m})$ & $49.6(d)$ & $0.94-1.02(\mathrm{~m})$ \\
\hline 10 & $36.5(s)$ & & $36.5(s)$ & & $36.4(s)$ & \\
\hline 11 & $21.0(t)$ & $\begin{array}{l}1.49-1.57\left(m, \mathrm{H}_{\alpha}\right) \\
1.38-1.48\left(m, \mathrm{H}_{\beta}\right)\end{array}$ & $21.1(t)$ & $\begin{array}{l}1.51-1.59\left(m, \mathrm{H}_{\alpha}\right) \\
1.41-1.51\left(m, \mathrm{H}_{\beta}\right)\end{array}$ & $20.9(t)$ & $\begin{array}{l}1.54-1.62\left(m, \mathrm{H}_{\alpha}\right) \\
1.42-1.50\left(m, \mathrm{H}_{\beta}\right)\end{array}$ \\
\hline 12 & $39.7(t)$ & $\begin{array}{l}1.12-1.24\left(m, \mathrm{H}_{\alpha}\right) \\
1.98-2.09\left(m, \mathrm{H}_{\beta}\right)\end{array}$ & $39.8(t)$ & $\begin{array}{l}1.12-1.24\left(m, \mathrm{H}_{\alpha}\right) \\
2.00-2.11\left(m, \mathrm{H}_{\beta}\right)\end{array}$ & $32.3(t)$ & $\begin{array}{l}1.42-1.50\left(m, \mathrm{H}_{\alpha}\right) \\
1.67-1.75\left(m, \mathrm{H}_{\beta}\right)\end{array}$ \\
\hline 13 & $42.4(s)$ & & $42.5(s)$ & & $47.3(s)$ & \\
\hline 14 & $56.7(d)$ & $0.95-1.10(\mathrm{~m})$ & $56.7(d)$ & $0.97-1.12(\mathrm{~m})$ & $50.9(d)$ & $1.68-1.76(\mathrm{~m})$ \\
\hline 15 & $24.2(t)$ & $\begin{array}{l}1.55-1.67\left(m, \mathrm{H}_{\alpha}\right), \\
1.13-1.21\left(m, \mathrm{H}_{\beta}\right)\end{array}$ & $24.2(t)$ & $\begin{array}{l}1.57-1.69\left(m, \mathrm{H}_{\alpha}\right), \\
1.13-1.21\left(m, \mathrm{H}_{\beta}\right)\end{array}$ & $23.6(t)$ & $\begin{array}{l}1.71-1.79\left(m, \mathrm{H}_{\alpha}\right) \\
1.12-1.20\left(m, \mathrm{H}_{\beta}\right)\end{array}$ \\
\hline 16 & $28.4(t)$ & $\begin{array}{l}1.84-1.98\left(m, \mathrm{H}_{\alpha}\right), \\
1.20-1.30\left(m, \mathrm{H}_{\beta}\right)\end{array}$ & $28.4(t)$ & $\begin{array}{l}1.82-1.96\left(m, \mathrm{H}_{\alpha}\right), \\
1.22-1.32\left(m, \mathrm{H}_{\beta}\right)\end{array}$ & $38.0(t)$ & $\begin{array}{l}1.86-1.92\left(m, \mathrm{H}_{\alpha}\right) \\
1.83-1.86\left(m, \mathrm{H}_{\beta}\right)\end{array}$ \\
\hline 17 & $56.8(d)$ & $1.10-1.26(\mathrm{~m})$ & $56.8(d)$ & $1.13-1.29(\mathrm{~m})$ & $87.5(s)$ & \\
\hline 18 & $11.8(q)$ & $0.67(s)$ & $11.9(q)$ & $0.73(s)$ & $14.5(q)$ & $0.76(s)$ \\
\hline 19 & $19.4(q)$ & $1.00(s)$ & $19.4(q)$ & $1.01(s)$ & $19.4(q)$ & $1.02(s)$ \\
\hline 20 & $34.1(d)$ & $1.36-1.49(\mathrm{~m})$ & $33.0(d)$ & $1.71-1.84(\mathrm{~m})$ & $41.6(d)$ & $1.69-1.77(m)$ \\
\hline 21 & $19.5(q)$ & $1.00(d, J=6.5)$ & $18.5(q)$ & $1.02(d, J=6.5)$ & $7.5(q)$ & $1.01(d, J=7.5)$ \\
\hline 22 & $42.6(t)$ & $\begin{array}{l}1.72-1.83(\mathrm{~m}), \\
1.21-1.35(\mathrm{~m})\end{array}$ & $43.6(t)$ & $\begin{array}{l}1.52-1.63(\mathrm{~m}), \\
1.11-1.25(\mathrm{~m})\end{array}$ & $71.5(d)$ & $4.19(d d, J=8.0,5.0)$ \\
\hline 23 & $74.4(d)$ & $4.20(t, J=6.7)$ & $71.1(d)$ & $4.16(d, J=10.2)$ & $40.6(t)$ & $\begin{array}{l}2.28(d d, J=14.0,5.0), \\
2.10(d d, J=14.0,5.0)\end{array}$ \\
\hline 24 & $159.2(s)$ & & $160.6(s)$ & & $152.7(s)$ & \\
\hline 25 & $29.8(d)$ & $2.18-2.40(\mathrm{~m})$ & $30.6(d)$ & $2.09-2.31(\mathrm{~m})$ & $33.6(d)$ & $2.18-2.28(\mathrm{~m})$ \\
\hline 26 & $23.1(q)$ & $1.08(d, J=6.8)$ & $22.5(q)$ & $1.05(d, J=7.0)$ & $21.8(q)$ & $1.04(d, J=6.5)$ \\
\hline 27 & $23.6(q)$ & $1.09(d, J=6.8)$ & $23.3(q)$ & $1.08(d, J=7.0)$ & $21.9(q)$ & $1.06(d, J=6.5)$ \\
\hline 28 & $108.1(t)$ & $5.02(s), 4.92(s)$ & $105.7(t)$ & $5.06(s), 4.88(s)$ & $109.5(t)$ & $4.90(s), 4.79(s)$ \\
\hline
\end{tabular}

$\left.{ }^{a}\right)$ Spectra were recorded in $\mathrm{CDCl}_{3}\left({ }^{1} \mathrm{H}: 300 \mathrm{MHz}\right.$ and $\left.\left.{ }^{13} \mathrm{C}: 75 \mathrm{MHz}\right) .{ }^{\text {b }}\right)$ Spectra were recorded in $\mathrm{CDCl}_{3}$ $\left({ }^{1} \mathrm{H}: 500 \mathrm{MHz}\right.$ and $\left.{ }^{13} \mathrm{C}: 125 \mathrm{MHz}\right)$.

basis of $\mathrm{HMBC}$ correlations, through $\mathrm{CH}_{2}(4) / \mathrm{C}(5)$ and $\mathrm{CH}_{2}(4) / \mathrm{C}(6)$. In addition, II and III were connected through the terminal methylidene based on HMBC correlations between $\mathrm{Me}(26), \mathrm{Me}(27) / \mathrm{C}(24), \mathrm{C}(25)$, and between $\mathrm{CH}_{2}(28) / \mathrm{C}(23), \mathrm{C}(24), \mathrm{C}(25)$. Rings $A$ and $B$ were elucidated on the basis of HMBC cross-peaks between $\mathrm{Me}(19) /$ $\mathrm{C}(1), \mathrm{C}(5), \mathrm{C}(9), \mathrm{C}(10)$ and $\mathrm{CH}_{2}(4) / \mathrm{C}(3)$, whereas rings $C$ and $D$ were determined 
based on HMBC correlations between Me(18)/C(12), C(13), C(14), C(17) (Fig. 1). NOESY Correlations observed between $\mathrm{H}_{\beta}-\mathrm{C}(11)$ and $\mathrm{H}-\mathrm{C}(8), \mathrm{H}_{\beta}-\mathrm{C}(11)$ and $\mathrm{Me}(18), \mathrm{H}_{\beta}-\mathrm{C}(11)$ and $\mathrm{Me}(19), \mathrm{H}-\mathrm{C}(9)$ and $\mathrm{H}-\mathrm{C}(14), \mathrm{Me}(18)$ and $\mathrm{H}-\mathrm{C}(8)$, $\mathrm{Me}(19)$ and $\mathrm{H}-\mathrm{C}(8), \mathrm{Me}(18)$ and $\mathrm{H}-\mathrm{C}(20), \mathrm{H}-\mathrm{C}(3)$ and $\mathrm{H}_{\alpha}-\mathrm{C}(1), \mathrm{Me}(21)$ and $\mathrm{H}_{\beta}-\mathrm{C}(12)$, and $\mathrm{Me}(19)$ and $\mathrm{H}_{\beta}-\mathrm{C}(4)$ in 1 confirmed the relative configurations for each ring junction and stereogenic center. By using a modified Mosher's method, the absolute configurations at $\mathrm{C}(3)$ and $\mathrm{C}(23)$ were established. Analysis of the $\Delta \delta\left(=\delta_{(S)}-\right.$ $\left.\delta_{(R)}\right)$ values (Table 2) according to the Mosher model [18][19] pointed to an $(S)$ configuration for $\mathrm{C}(23)$ of $\mathbf{1}$, because $\mathrm{H}-\mathrm{C}(25), \mathrm{Me}(26), \mathrm{Me}(27)$, and $\mathrm{CH}_{2}(28)$ of $(R)$ MTPA ester 1b were more shielded by the phenyl ring of MTPA ( $=\alpha$-methoxy- $\alpha$ (trifluoromethyl)phenylacetic acid) products. We thereby revised the absolute configuration at $\mathrm{C}(23)$ in the side chain of some lanostanoids which were isolated from the bark and leaves of Amentotaxus formosana [16][17]. Thus, the structure of $\mathbf{1}$ was established unambiguously.

Compound 2, a white amorphous powder, was found to possess the same molecular formula as that of $\mathbf{1}\left(\mathrm{C}_{28} \mathrm{H}_{46} \mathrm{O}_{2}\right)$, as revealed by HR-ESI-MS. The spectral data of $\mathbf{2}$ ( Table 1) differed from 1 only for $\mathrm{C}(23)(\delta(\mathrm{H}) 4.20(t, J=6.7,1 \mathrm{H}), \delta(\mathrm{C}) 74.4$ of 1 and $\delta(\mathrm{H}) 4.16(d, J=10.2,1 \mathrm{H}), \delta(\mathrm{C}) 71.1$ of 2$)$. The above result, together with the comparison of 2D-NMR spectral data of $\mathbf{2}$ with those of $\mathbf{1}$, disclosed that the two compounds were epimers. The significant ${ }^{1} \mathrm{H}$ and ${ }^{13} \mathrm{C}$ chemical-shift differences between $\mathbf{1}$ and $\mathbf{2}$ demonstrated that $\mathrm{C}(23)$ of $\mathbf{2}$ possessed the $(R)$-configuration. From

Table 2. Selected ${ }^{1} H$-NMR Data of Mosher's Esters of $\mathbf{1}$ and 3. $\delta$ in ppm.

\begin{tabular}{|c|c|c|c|c|c|c|c|}
\hline \multirow[t]{2}{*}{ Position } & \multicolumn{3}{|l|}{$\left.\mathbf{1}^{\mathrm{a}}\right)$} & \multirow[t]{2}{*}{ Position } & \multicolumn{3}{|l|}{$\left.\mathbf{3}^{\mathrm{a}}\right)$} \\
\hline & $\begin{array}{l}(S) \text {-MTPA } \\
\mathbf{1 a}\end{array}$ & $\begin{array}{l}(R)-\mathrm{MTPA} \\
\mathbf{1 b}\end{array}$ & $\Delta \delta$ & & $\begin{array}{l}(S) \text {-MTPA } \\
\mathbf{3 a}\end{array}$ & $\begin{array}{l}(R) \text {-MTPA } \\
\text { 3b }\end{array}$ & $\Delta \delta$ \\
\hline 2 & $\begin{array}{l}1.9814 \\
1.5857\end{array}$ & $\begin{array}{l}2.0195 \\
1.6786\end{array}$ & $\begin{array}{l}-0.0381 \\
-0.0929\end{array}$ & 2 & $\begin{array}{l}1.8579 \\
1.5713\end{array}$ & $\begin{array}{l}1.9147, \\
1.6853\end{array}$ & $\begin{array}{l}-0.0568 \\
-0.1140\end{array}$ \\
\hline 4 & $\begin{array}{l}2.5685 \\
2.5385\end{array}$ & $\begin{array}{l}2.5227 \\
2.4623\end{array}$ & $\begin{array}{l}+0.0458 \\
+0.0762\end{array}$ & 4 & $\begin{array}{l}2.4941 \\
2.4435\end{array}$ & $\begin{array}{l}2.4679 \\
2.4059\end{array}$ & $\begin{array}{l}+0.0251 \\
+0.0376\end{array}$ \\
\hline 6 & 5.4314 & 5.3997 & +0.0317 & 6 & 5.3490 & 5.3100 & +0.0390 \\
\hline 7 & $\begin{array}{l}1.9118 \\
1.5470\end{array}$ & $\begin{array}{l}1.8645 \\
1.5113\end{array}$ & $\begin{array}{l}+0.0473 \\
+0.0357\end{array}$ & 7 & $\begin{array}{l}1.8579 \\
1.5385\end{array}$ & $\begin{array}{l}1.8216 \\
1.5054\end{array}$ & $\begin{array}{l}+0.0363 \\
+0.0331\end{array}$ \\
\hline 18 & 0.6442 & 0.6682 & -0.0240 & 18 & 0.7751 & 0.7530 & +0.0221 \\
\hline 19 & 0.9123 & 0.9161 & -0.0038 & 19 & 0.8976 & 0.8878 & +0.0098 \\
\hline 20 & 1.4855 & 1.5391 & -0.0536 & 20 & 2.2400 & 2.1343 & +0.1057 \\
\hline 21 & 1.0191 & 1.0375 & -0.0184 & 21 & 1.2850 & 1.2406 & +0.0444 \\
\hline 22 & $\begin{array}{l}1.9363 \\
1.6348\end{array}$ & $\begin{array}{l}2.0013 \\
1.6612\end{array}$ & $\begin{array}{l}-0.0650 \\
-0.0264\end{array}$ & 23 & $\begin{array}{l}2.4941 \\
2.2320\end{array}$ & $\begin{array}{l}2.6356 \\
2.4679\end{array}$ & $\begin{array}{l}-0.1415 \\
-0.1490\end{array}$ \\
\hline 25 & 2.4619 & 2.3914 & +0.0705 & 25 & 2.3801 & 2.4059 & -0.0258 \\
\hline 26 & 1.1232 & 1.1113 & +0.0119 & 26 & 1.0140 & 1.0396 & -0.0256 \\
\hline 27 & 1.1557 & 1.1332 & +0.0225 & 27 & 1.0366 & 1.0587 & -0.0221 \\
\hline 28 & $\begin{array}{l}5.3134 \\
5.1600\end{array}$ & $\begin{array}{l}5.2047 \\
5.0908\end{array}$ & $\begin{array}{l}+0.1087 \\
+0.0692\end{array}$ & 28 & 4.8689 & 4.992 & -0.1231 \\
\hline
\end{tabular}

a) Spectra were recorded in $\mathrm{C}_{5} \mathrm{D}_{5} \mathrm{~N}(300 \mathrm{MHz})$. 
the aforementioned data, the structure of $\mathbf{2}$ was assigned as $(3 \beta, 23 R)$-ergosta-5,24(28)diene-3,23-diol.

Compound 3 had a molecular formula of $\mathrm{C}_{28} \mathrm{H}_{46} \mathrm{O}_{3}$ as determined by HR-ESI-MS. IR Spectrum showed the presence of $\mathrm{OH}$ group(s) $\left(3332 \mathrm{~cm}^{-1}\right)$. The presence of two $\mathrm{CH}-\mathrm{O}$ groups and one O-bearing quaternary C-atom were inferred from ${ }^{1} \mathrm{H}-\mathrm{NMR}$ $(\delta(\mathrm{H}) 3.51-3.57(m, 1 \mathrm{H}), 4.19(d d, J=8.0,5.0,1 \mathrm{H}))$ and ${ }^{13} \mathrm{C}-\mathrm{NMR}(\delta(\mathrm{C}) 71.7,71.5$, and 87.5) spectra. ${ }^{1} \mathrm{H}$ - and ${ }^{13} \mathrm{C}-\mathrm{NMR}$ spectra also exhibited signals due to five $\mathrm{Me}$ groups $(\delta(\mathrm{H}) 0.76(s, 3 \mathrm{H}), 1.02(s, 3 \mathrm{H}), 1.04(d, J=6.5,3 \mathrm{H}), 1.06(d, J=6.5,3 \mathrm{H}), 1.01$ $(d, J=7.5,3 \mathrm{H}))$, and a trisubstituted $\mathrm{C}=\mathrm{C}$ bond $(\delta(\mathrm{H}) 5.36($ br. $d, J=5.0,1 \mathrm{H}), \delta(\mathrm{C})$ 121.6 and 140.6), and a terminal $\mathrm{C}=\mathrm{C}$ bond $(\delta(\mathrm{H}) 4.90,4.79(s$, each $1 \mathrm{H}), \delta(\mathrm{C}) 109.5$ and 152.7). ${ }^{13} \mathrm{C}$-NMR and DEPT spectra of $\mathbf{3}$ also exhibited 28 signals, including those of five $\mathrm{Me}$, ten $\mathrm{CH}_{2}$, eight $\mathrm{CH}$ groups, and five quaternary $\mathrm{C}$-atoms. This evidence suggested that $\mathbf{3}$ possessed the similar steroid skeleton $(A, B, C$, and $D$ rings) as of ergosta-5,24(28)-dien-3 $\beta$-ol except for the presence of additional $\mathrm{OH}$ groups at $\mathrm{C}(17)$ and $\mathrm{C}(22)$, which were confirmed by COSY and HMBC spectra of $\mathbf{3}$ (Fig. 1). By using Mosher's method [18][19], the absolute configuration at $\mathrm{C}(22)$ was readily defined by the analysis of NMR-shift data of the corresponding C(22) $(S)$ - and $(R)$-MTPA esters. The significant ${ }^{1} \mathrm{H}-\mathrm{NMR}$ chemical-shift differences between the $(S)$ - and $(R)$-MTPA esters 3a and $\mathbf{3 b}$ demonstrated that $\mathrm{C}(22)$ possessed the $(S)$-configuration (Table 2), because $\mathrm{CH}(25), \mathrm{Me}(26), \mathrm{Me}(27)$, and $\mathrm{CH}_{2}(28)$ of $(R)$-MTPA ester $\mathbf{3 b}$ were more shielded by the phenyl ring of MTPA products. In addition, the $\Delta$ value $\left(\delta_{\mathrm{CDCl}_{3}}-\delta_{\mathrm{C}_{5} \mathrm{D}_{5} \mathrm{~N}}\right)$ of the $\mathrm{Me}(18) \mathrm{H}$-atoms $(300 \mathrm{MHz})$ of $\mathbf{3}$ in two different solvents $\left(\mathrm{CDCl}_{3}\right.$ and $\left(\mathrm{D}_{5}\right)$ pyridine $\left.\left(\mathrm{C}_{5} \mathrm{D}_{5} \mathrm{~N}\right)\right)$ is small $(-0.02 \mathrm{ppm})$, whereas the dihedral angle between the $\mathrm{OH}$ group and the Me group is large, indicating the $\alpha$-orientation of $\mathrm{OH}$ at $\mathrm{C}(17)$ [20]. Therefore, the structure of $\mathbf{3}$ was assigned as $(3 \beta, 22 S)$-ergosta-5,24(28)-diene-3,17,22-triol.

Compound 5 was obtained as a colorless oil. According to HR-EI-MS $(\mathrm{m} / \mathrm{z}$ 176.1202 $\left(M^{+}\right)$) and ${ }^{13} \mathrm{C}-\mathrm{NMR}$ data, its molecular formula was established as $\mathrm{C}_{12} \mathrm{H}_{16} \mathrm{O}$, indicating five degrees of unsaturation. UV Spectrum displayed a $\lambda_{\max }(\mathrm{MeOH})$ value of $241 \mathrm{~nm}$, indicating the presence of a cyclohexa-2,5-dienone moiety, supported by an IR absorption at $1657 \mathrm{~cm}^{-1}$ (conjugated $\mathrm{C}=\mathrm{O}$ group). In addition, the ${ }^{1} \mathrm{H}$ - and ${ }^{13} \mathrm{C}-\mathrm{NMR}$ spectra (Table 3 ) of $\mathbf{5}$ contained resonances for a cyclohexa-2,5-dienone moiety $(\delta(\mathrm{H}) 6.12(d, J=1.5,1 \mathrm{H}), 6.22(d d, J=10.0,1.5,1 \mathrm{H})$, and $6.78(d, J=10.0$, $1 \mathrm{H}) ; \delta(\mathrm{C}) 171.0,121.5,187.5,126.4$, and 158.1). Thus, $\mathbf{5}$ was suggested to be a bicyclic structure. From the COSY spectrum of $\mathbf{5}$ (Fig. 1), it was possible to establish the Hatom sequence from $\mathrm{CH}_{2}(5)$ to $\mathrm{Me}(9) .{ }^{1} \mathrm{H},{ }^{1} \mathrm{H}$-COSY correlations further observed between $\mathrm{CH}(3)$ and $\mathrm{CH}(4)$ indicated the $(Z)$-form olefinic coupling $(J=10.0 \mathrm{~Hz})$. The connectivities between $\mathrm{C}(4 \mathrm{a})$ and $\mathrm{C}(4), \mathrm{C}(5)$, and $\mathrm{C}(8 \mathrm{a})$ were confirmed by HMBC correlations of $\mathrm{Me}(10)$ with $\mathrm{C}(4), \mathrm{C}(4 \mathrm{a}), \mathrm{C}(5)$, and $\mathrm{C}(8 \mathrm{a})$. Furthermore, HMBC correlations from $\mathrm{Me}(9)$ to $\mathrm{C}(8)$ and $\mathrm{C}(8 \mathrm{a})$, suggested that $\mathrm{C}(8)$ and $\mathrm{C}(8 \mathrm{a})$ were connected. The relative configuration of $\mathbf{5}$ was determined by NOESY data (Fig. 2). NOE Correlations from $\mathrm{H}-\mathrm{C}(8)$ to $\mathrm{H}_{\alpha}-\mathrm{C}(7), \mathrm{H}_{\alpha}-\mathrm{C}(5)$, and $\mathrm{Me}(10)$ suggested that these $\mathrm{H}$-atoms were oriented on the same side. NOE Correlations also indicated that $\mathrm{H}_{\beta}-\mathrm{C}(5)$ and $\mathrm{H}_{\beta}-\mathrm{C}(6), \mathrm{H}_{\beta}-\mathrm{C}(6)$ and $\mathrm{H}_{\beta}-\mathrm{C}(7)$, and $\mathrm{H}_{\beta}-\mathrm{C}(7)$ and $\mathrm{Me}(9)$ were on the opposite side. From the aforementioned data, $\mathbf{5}$ was determined as $\left(4 \mathrm{a} S^{*}, 8 S^{*}\right)-5,6,7,8$-tetrahydro-4a,8-dimethylnaphthalen-2(4aH)-one. An isomer $\left(4 \mathrm{a} R^{*}, 8 S^{*}\right)-5,6,7,8$-tetrahydro-4a,8-dimethylnaphthalen-2(4aH)-one of $\mathbf{5}$ had been 
Table 3. ${ }^{1} H$ - and ${ }^{13} \mathrm{C}-\mathrm{NMR}$ Data of 5 and $\mathbf{6}$. At 500 and $300 \mathrm{MHz}$, resp., $\delta$ in ppm, $J$ in Hz.

\begin{tabular}{|c|c|c|c|c|}
\hline \multirow[t]{2}{*}{ Position } & \multicolumn{2}{|l|}{$\left.\mathbf{5}^{\mathrm{a}}\right)$} & \multicolumn{2}{|l|}{$\left.6^{\mathrm{a}}\right)$} \\
\hline & $\delta(\mathrm{C})$ & $\delta(\mathrm{H})$ & $\delta(\mathrm{C})$ & $\delta(\mathrm{H})$ \\
\hline 1 & $121.5(d)$ & $6.12(d, J=1.5)$ & $130.0(d)$ & 7.73 (br. $s$ ) \\
\hline 2 & $187.5(s)$ & & $141.1(s)$ & \\
\hline 3 & $126.4(d)$ & $6.22(d d, J=10.0,1.5)$ & $126.7(d)$ & 7.64 (br. $d, J=7.9$ ) \\
\hline 4 & $158.1(d)$ & $6.78(d, J=10.0)$ & $127.9(d)$ & $7.39(d, J=7.9)$ \\
\hline $4 a$ & $41.2(s)$ & & $150.7(s)$ & \\
\hline 5 & $38.5(t)$ & $\begin{array}{l}1.80-1.86\left(m, \mathrm{H}_{\alpha}\right), \\
1.33-1.35\left(m, \mathrm{H}_{\beta}\right)\end{array}$ & $33.4(d)$ & $2.83-2.93(\mathrm{~m})$ \\
\hline 6 & $21.0(t)$ & $\begin{array}{l}1.78-1.85\left(m, \mathrm{H}_{\alpha}\right), \\
1.66-1.73\left(m, \mathrm{H}_{\beta}\right)\end{array}$ & $30.1(t)$ & $\begin{array}{l}1.32-1.42\left(m, \mathrm{H}_{\alpha}\right), \\
1.92-2.08\left(m, \mathrm{H}_{\beta}\right)\end{array}$ \\
\hline 7 & $37.0(t)$ & $\begin{array}{l}1.95-2.03\left(m, \mathrm{H}_{\alpha}\right) \\
1.04-1.10\left(m, \mathrm{H}_{\beta}\right)\end{array}$ & $21.1(t)$ & $1.59-1.69\left(m, \mathrm{H}_{\beta}\right)$ \\
\hline 8 & $34.1(d)$ & $2.46-2.54(\mathrm{~m})$ & $43.8(d)$ & $2.79($ br. $d d, J=12.5,6.3)$ \\
\hline $8 a$ & $171.0(s)$ & & $134.0(s)$ & \\
\hline 9 & $17.7(q)$ & $1.14(d, J=7.0)$ & $32.0(d)$ & $2.22-2.32(\mathrm{~m})$ \\
\hline 10 & $23.4(q)$ & $1.27(s)$ & $17.4(q)$ & $0.73(d, J=6.8)$ \\
\hline 11 & & & $21.2(q)$ & $1.03(d, J=6.8)$ \\
\hline 12 & & & $22.1(q)$ & $1.31(d, J=7.0)$ \\
\hline 13 & & & $192.5(d)$ & $9.96(s)$ \\
\hline
\end{tabular}

a) Spectra were recorded in $\mathrm{CDCl}_{3}$.

prepared as an intermediate in a spirovetivane synthesis [21]. The assignments of $\mathbf{5}$ were disclosed (Table 3) by extensive 2D-NMR data analyses for the first time.

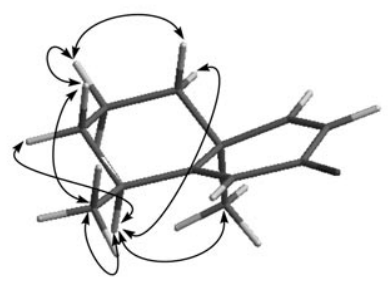

5

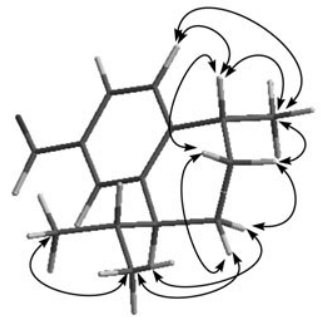

6

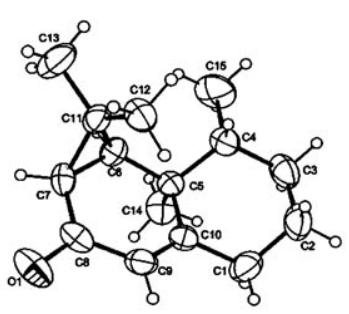

7

Fig. 2. Selected NOESY correlations of $\mathbf{5}$ and $\mathbf{6}$, and X-ray ORTEP representation of $\mathbf{7}$

HR-ESI-MS of (+)-trans-calamenen-13-al (6), a canary yellow syrup, showed a molecular formula of $\mathrm{C}_{15} \mathrm{H}_{20} \mathrm{O}$, implying six degrees of unsaturation. IR Spectrum of 6 indicated the presence of a conjugated benzaldehyde function $\left(2867\right.$ and $\left.1695 \mathrm{~cm}^{-1}\right)$. The UV absorption maximum at $262 \mathrm{~nm}$ confirmed the aforementioned function. The NMR spectra (Table 3) indicated a trisubstituted phenyl moiety $\left({ }^{1} \mathrm{H}-\mathrm{NMR}: \delta(\mathrm{H}) 7.39\right.$, $7.64(d, J=7.9,1 \mathrm{H}$ each), and 7.73 (br. $s, 1 \mathrm{H}) ;{ }^{13} \mathrm{C}-\mathrm{NMR} \delta(\mathrm{C}) 127.9,126.7,130.0,141.1$, 134.0, and 150.7). The ${ }^{13} \mathrm{C}-\mathrm{NMR}$ and DEPT spectra revealed 15 signals, including those for three $\mathrm{Me}$, two $\mathrm{CH}_{2}$, seven $\mathrm{CH}$ groups, and three quaternary $\mathrm{C}$-atoms. The above 
data of 6 were similar to those of (-)-trans-calamenene [22], except for the replacement of the Me by an carbaldehyde group $(\delta(\mathrm{H}) 9.96(s, 1 \mathrm{H})$ and $\delta(\mathrm{C}) 192.5$ $(d)$ ) at $\mathrm{C}(2)$. This was supported by the HMBC spectrum (Fig. 1) and long-range ${ }^{1} \mathrm{H},{ }^{13} \mathrm{C}$-correlations from $\mathrm{CH}(1)$ to $\mathrm{C}(13)$ ). NOESY Correlations (Fig. 2) between $\mathrm{H}_{\alpha}-\mathrm{C}(6)$ and the $\mathrm{H}$-atoms of $\mathrm{H}_{\alpha}-\mathrm{C}(7)$ and $\mathrm{Me}(12)$, and between $\mathrm{H}_{\alpha}-\mathrm{C}(7)$ and $\mathrm{H}-\mathrm{C}(8)$ suggested that these $\mathrm{H}$-atoms were oriented on the same side of the cyclohexene moiety, in which the i-Pr group at $\mathrm{C}(8)$ was oriented on the opposite side. The absolute configuration of $\mathbf{6}$ was further established by comparison of its optical rotation with that of (-)-trans-calamenene [22]. On the basis of these evidences, the structure of 6 was established unambiguously.

Compound 7, identified by comparison of spectral data with those of (-)-aristolone [15], was obtained as a colorless hexagonal crystal from hexane. The absolute configuration of aristol-9-en-8-one (7) was further confirmed by X-ray diffraction analyses (Fig. 2) [23].

Compounds 1-4 and $\mathbf{7}$ were tested for cytotoxicity against P-388 (mouse lymphocytic leukemia) and HT-29 (human colon adenocarcinoma) cancer cell lines. The results showed that compounds 1, 2, 4, and $\mathbf{7}$ were not cytotoxic against these two cancer cell lines. However, compound $\mathbf{3}$ exhibited cytotoxicity against P-388 cell line with an $E D_{50}$ value of $3.7 \mu \mathrm{g} / \mathrm{ml}$. The anticancer agent mithramycin was used as the positive control and exhibited an $E D_{50}$ value of 0.06 and $0.08 \mu \mathrm{g} / \mathrm{ml}$ against P-388 and HT-29 cells, respectively. In addition, as shown in Fig. 3, the in vitro anti-inflammatory activity of compounds $\mathbf{1}-\mathbf{7}$ was tested using LPS-stimulated cell. Stimulation of RAW 264.7 cell with LPS resulted in up-regulation of the pro-inflammatory iNOS (inducible nitric oxide synthetase) and COX-2 (cyclooxygenase-2) protein. Both compounds 1 and $\mathbf{3}$, at a concentration of $10 \mu \mathrm{M}$, significantly reduced the levels of the iNOS (45.8 \pm 9.9 and $33.6 \pm 20.6 \%$, resp.) and COX-2 protein (68.1 \pm 2.3 and $10.3 \pm 6.2 \%$, resp.) compared with the control cells stimulated with LPS. At the same concentration, compounds 2 and $\mathbf{4}$ did not inhibit the COX-2 protein expression, but significantly
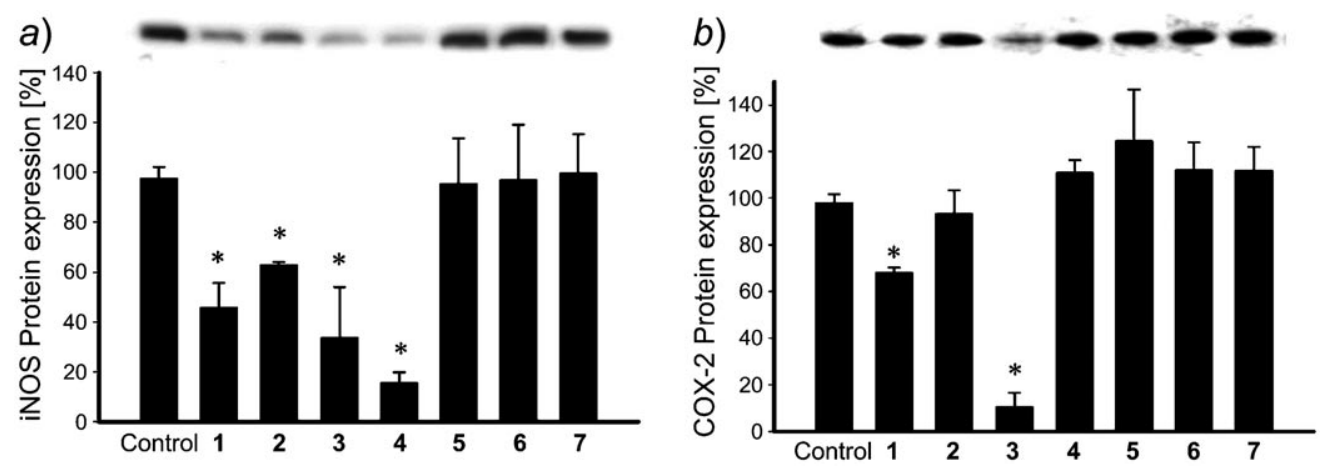

Fig. 3. Effect of compounds 1-7 at $10 \mu \mathrm{M}$ concentration on the LPS-induced pro-inflammatory iNOS and COX-2 protein expression of RAW264.7 macrophage cells by immunoblot analysis. a) Immunoblot of iNOS; $b)$ immunoblot of COX-2. The values are mean $\pm \operatorname{SEM}(n=5)$. Relative intensity of the LPSalone-stimulated group was taken as $100 \%$. *: Significantly different from LPS-stimulated (control) group $(P<0.05)$. 
inhibited iNOS protein expression (62.8 \pm 1.3 and $15.6 \pm 4.1 \%$, resp., compared with control cells) by LPS stimulation. Moreover, cell survival was not changed by the presence of compounds 1-7 at the same concentration. Under the same experimental conditions, $10 \mu \mathrm{M}$ CAPE (caffeic acid phenylthyl ester; Sigma Chemical. Company, St. Louis, MO) reduced the levels of the iNOS and COX-2 protein to $1.5 \pm 2.1$ and $70.2 \pm$ $11.5 \%$, respectively, relative to the control cells stimulated with LPS.

Financial support was provided by Ministry of Education (95C030313) and National Science Council of Taiwan (96-2320-B-110-003-MY3) awarded to C.-Y. D.

\section{Experimental Part}

General. Silica gel 60 (Merck, 230-400 mesh) was used for column chromatography (CC); precoated Si gel plates (Merck, Kieselgel $60 F_{254}, 0.25 \mathrm{~mm}$ ) were used for TLC. High-performance liquid chromatography (HPLC): a Hitachi $L-7420$ UV detector $L-7100$ pump apparatus equipped with Merck Hibar RP-18e column $(250 \times 10 \mathrm{~mm}, 5 \mu \mathrm{m})$. Optical rotations: JASCO P1020 polarimeter. UV Spectra: Hitachi $U$-3210 spectrophotometer. IR Spectra: JASCO FT/IR-4100 spectrophotometer. NMR Spectra: Bruker Avance $300 \mathrm{NMR}$ spectrometer at $300 \mathrm{MHz}$ for ${ }^{1} \mathrm{H}$ and $75 \mathrm{MHz}$ for ${ }^{13} \mathrm{C}$, or Varian Unity INOVA 500 FT-NMR spectrometer at $500 \mathrm{MHz}$ for ${ }^{1} \mathrm{H}$ and $125 \mathrm{MHz}$ for ${ }^{13} \mathrm{C}$, with TMS as internal standard; chemical shifts in $\delta(\mathrm{ppm})$ and coupling constants $J$ in Hz. ESI-MS: ESI-FT-MS on a Bruker APEX II mass spectrometer. EI-MS: JEOL JMSSX/SX $102 \mathrm{~A}$ mass spectrometer at $70 \mathrm{eV}$.

Soft Coral Material. The soft coral $N$. erecta was collected by hand using scuba at Green Island located in the southeast coast of Taiwan, in July 2005, at a depth of $10 \mathrm{~m}$, and was stored in a freezer for 5 weeks until extraction. This specimen was identified by Prof. Chang-Feng Dai, and a voucher specimen (GN-80) was deposited with the Department of Marine Biotechnology and Resources, National Sun Yatsen University.

Extraction and Isolation. A specimen of $N$. erecta was extracted sequentially with fresh acetone and $\mathrm{MeOH}$ at r.t. The combined acetone extracts were concentrated to a brown gum, which was partitioned between $\mathrm{H}_{2} \mathrm{O}$ and AcOEt. The AcOEt extract ( $35.0 \mathrm{~g}$ ) was chromatographed over a silica-gel column using hexane, hexane/AcOEt, and $\mathrm{AcOEt} / \mathrm{MeOH}$ mixtures of increasing polarity. Elution with hexane gave fractions containing compounds $\mathbf{6}$ and 7, and elution with hexane/AcOEt 90:10 gave fractions containing compounds $\mathbf{1}, \mathbf{2}, \mathbf{3}$, and 4 . Compounds $6(5 \mathrm{mg})$ and $\mathbf{7}(5 \mathrm{mg})$ were further purified by HPLC ( $\mathrm{Si})$ by eluting with hexane. Compounds $\mathbf{1}(7 \mathrm{mg}), \mathbf{2}(2 \mathrm{mg}), \mathbf{3}(14 \mathrm{mg})$, and $\mathbf{4}(10 \mathrm{mg})$ were further purified by $R P-18$ HPLC $\left(95 \% \mathrm{MeOH}\right.$ in $\left.\mathrm{H}_{2} \mathrm{O}\right)$. In addition, the combined $\mathrm{MeOH}$ extract was concentrated to a brown gum, which was partitioned between $\mathrm{H}_{2} \mathrm{O}$ and AcOEt. The AcOEt extract was chromatographed over a silica-gel column using $\mathrm{CH}_{2} \mathrm{Cl}_{2}$ and $\mathrm{MeOH}$ mixtures of increasing polarity. A fraction (eluted from $90 \% \mathrm{CH}_{2} \mathrm{Cl}_{2}$ in $\mathrm{MeOH}$ ) was subjected to repeated $R P-18 \mathrm{HPLC}(60 \% \mathrm{MeOH}$ in $\left.\mathrm{H}_{2} \mathrm{O}\right)$ to afford $5(1 \mathrm{mg})$.

(3ß,23S)-Ergosta-5,24(28)-diene-3,23-diol (1). White amorphous powder. $[\alpha]_{\mathrm{D}}^{23}=+16(c=0.7$, $\mathrm{CHCl}_{3}$ ). IR (KBr): 3323, 2925, 1465, 1374, 1055, 901, 799. ${ }^{1} \mathrm{H}-$ and ${ }^{13} \mathrm{C}-\mathrm{NMR}$ : see Table 1. ESI-MS (pos.): $437\left([M+\mathrm{Na}]^{+}\right)$. HR-ESI-MS: $437.3392\left([M+\mathrm{Na}]^{+}, \mathrm{C}_{28} \mathrm{H}_{46} \mathrm{NaO}_{2}^{+}\right.$; calc. 437.3395).

$(3 \beta, 23 \mathrm{R})$-Ergosta-5,24(28)-diene-3,23-diol (2). White amorphous powder. $[\alpha]_{\mathrm{D}}^{23}=+96(c=0.2$, $\mathrm{CHCl}_{3}$ ). IR (KBr): 3332, 2929, 1465, 1374, 1059, 902, 803. ${ }^{1} \mathrm{H}$ - and ${ }^{13} \mathrm{C}-\mathrm{NMR}$ : see Table 1. ESI-MS (pos.): $437\left([M+\mathrm{Na}]^{+}\right)$. HR-ESI-MS: $437.3394\left([M+\mathrm{Na}]^{+}, \mathrm{C}_{28} \mathrm{H}_{46} \mathrm{NaO}_{2}^{+}\right.$; calc. 437.3395).

$(3 \beta, 22 \mathrm{~S})$-Ergosta-5,24(28)-diene-3,17,22-triol (3). White amorphous powder. $[\alpha]_{\mathrm{D}}^{23}=+14(c=0.7$, $\mathrm{CHCl}_{3}$ ). IR (KBr): 3332, 2929, 1438, 1369, 1095, 1054, 892, 767. ${ }^{1} \mathrm{H}-$ and ${ }^{13} \mathrm{C}-\mathrm{NMR}$ : see Table 1. ESI-MS (pos.): $453\left([M+\mathrm{Na}]^{+}\right)$. HR-ESI-MS: $453.3345\left([M+\mathrm{Na}]^{+}, \mathrm{C}_{28} \mathrm{H}_{46} \mathrm{NaO}_{3}^{+}\right.$; calc. 453.3344).

$\left(4 a \mathrm{~S}^{*}, 8 \mathrm{~S} *\right)-5,6,7,8-$ Tetrahydro-4a,8-dimethylnaphthalen-2(4aH)-one (5). Colorless oil. $[\alpha]_{\mathrm{D}}^{23}=+128$ $\left(c=0.1, \mathrm{CHCl}_{3}\right)$. UV (MeOH): 241 (3.98). IR ( KBr): 2926, 1657, 1461, 1378, 749. ${ }^{1} \mathrm{H}$ - and ${ }^{13} \mathrm{C}-\mathrm{NMR}$ : see Table 3. EI-MS: $176\left(M^{+}\right)$. HR-EI-MS: $176.1202\left(M^{+}, \mathrm{C}_{12} \mathrm{H}_{16} \mathrm{O}^{+}\right.$; calc. 176.1201).

(5S,8R)-5,6,7,8-Tetrahydro-5-methyl-8-(1-methylethyl)naphthalene-2-carbaldehyde (6). Canary yellow syrup. $[\alpha]_{\mathrm{D}}^{23}=+42\left(c=0.5, \mathrm{CHCl}_{3}\right)$. UV $(\mathrm{MeOH}): 262$ (3.18). IR $(\mathrm{KBr}): 2952,2867,1695,1603$, 
1564, 1456, 1379, 902, 824. ${ }^{1} \mathrm{H}$ - and ${ }^{13} \mathrm{C}-\mathrm{NMR}$ : see Table 3. ESI-MS (pos.): $217\left([\mathrm{M}+\mathrm{H}]^{+}\right)$. HR-ESI-MS: $217.1594\left([M+\mathrm{H}]^{+}, \mathrm{C}_{15} \mathrm{H}_{21} \mathrm{O}^{+} ;\right.$calc. 217.1592).

Preparation of $(\mathrm{R})$ - and $(\mathrm{S})-M T P A(=\alpha-$ Methoxy- $\alpha-($ trifluoromethyl)phenylacetic Acid $)$ Esters of $\mathbf{1}$ and 3. Two aliquots of $\mathbf{1}(1 \mathrm{mg})$ were dissolved in $\left(\mathrm{D}_{5}\right)$ pyridine $\left(\mathrm{C}_{5} \mathrm{D}_{5} \mathrm{~N} ; 0.6 \mathrm{ml}\right)$ and allowed to react overnight with $(R)$ - and ( $S$-MTPA chloride (one drop), affording the $(S)$ - and $(R)$-MTPA esters 1a and 1b, resp. In the same manner, $3(1 \mathrm{mg})$ was dissolved in $\mathrm{C}_{5} \mathrm{D}_{5} \mathrm{~N}(0.6 \mathrm{ml})$ and reacted with $(R)$ - and $(S)$ MTPA chloride to afford $(S)$-MTPA ester 3a and $(R)$-MTPA ester 3b, resp. Selected $\Delta \delta$ values were shown in Table 2.

Cytotoxicity Testing. P-388 Cells were kindly supplied by Prof. J. M. Pezzuto, formerly of the Department of Medicinal Chemistry and Pharmacognosy, University of Illinois at Chicago; HT-29 cells were purchased from the American Type Culture Collection (ATCC). Cytotoxicity assays of the tested compounds were performed on the basis of a MTT assay method. The experimental details about the biological assay were carried out according to the procedure described in [24].

In vitro Anti-Inflammatory Assay. The anti-inflammatory assay was modified from $\mathrm{Ho}$ et al. [25] and Park et al. [26]. Murine RAW 264.7 macrophages were obtained from ATCC (No. TIB-71). The cells were activated by incubation in a medium containing Escherichia coli LPS $(0.01 \mu \mathrm{g} / \mathrm{ml} ;$ Sigma $)$ for $16 \mathrm{~h}$ in the presence or absence of various compounds. Then, cells were washed with ice-cold phosphate-buffered saline (PBS), lysed in ice cold lysis buffer, and then centrifuged at $20000 \mathrm{~g}$ for $30 \mathrm{~min}$ at $4^{\circ}$. The supernatant was decanted from the pellet and retained for Western blot analysis. Protein concentrations were determined by the DC protein assay kit (Bio-Rad) modified by the method of Lowry et al. [27]. Samples containing equal quantities of protein were subjected to sodium dodecyl sulfate (SDS)polyacrylamide gel electrophoresis, and the separated proteins were electrophoretically transferred to polyvinylidene difluoride membranes (PVDF; Immobilon-P, Millipore, $0.45-\mu \mathrm{m}$ pore size). The resultant PVDF membranes were incubated with blocking soln. and incubated for $180 \mathrm{~min}$ with antibody against inducible nitric oxide synthase (iNOS; 1:1000 dilution; Transduction Laboratories) and cyclooxygenase2 (COX-2; 1:1000 dilution; Cayman Chemical) protein. The blots were detected using enhanced chemiluminescence (ECL) detection reagents (Perkin-Elmer, Western Blot Chemiluminescence Reagent Plus) according to the manufacturer instructions.

\section{REFERENCES}

[1] J. W. Blunt, B. R. Copp, W.-P. Hu, M. H. G. Munro, P. T. Northcote, M. R. Prinsep, Nat. Prod. Rep. $\mathbf{2 0 0 7}, 24,31$, and refs. cit. in previous reviews.

[2] J. C. Coll, B. F. Bowden, D. M. Tapiolas, R. H. Willis, Tetrahedron 1985, 41, 1085.

[3] B. F. Bowden, J. C. Coll, S. J. Mitchell, Aust. J. Chem. 1980, 33, 1833.

[4] A. J. Blackman, B. F. Bowden, J. C. Coll, B. Frick, M. Mahendran, S. J. Mitchell, Aust. J. Chem. 1982, $35,1873$.

[5] C.-Y. Duh, S.-K. Wang, Y.-L. Weng, Tetrahedron Lett. 2000, 41, 1401.

[6] C.-Y. Duh, S.-K. Wang, M.-J. Chu, J.-H. Sheu, J. Nat. Prod. 1998, 61, 1022.

[7] A. A. H. El-Gamal, S.-K. Wang, C.-F. Dai, C.-Y. Duh, J. Nat. Prod. 2004, 67, 1455.

[8] W.-H. Zhang, I. D. Williams, C.-T. Che, Tetrahedron Lett. 2001, 42, 4681.

[9] I. Kitagawa, Z. Cui, B. W. Son, M. Kobayashi, Y. Kyogoku, Chem. Pharm. Bull. 1987, 35, 124.

[10] M. R. Rao, U. Venkatesham, Y. Venkateswarlu, J. Nat. Prod. 1999, 62, 1584.

[11] S. E. Poet, B. N. Ravi, Aust. J. Chem. 1982, 35, 77.

[12] D. Handayani, R. A. Edrada, P. Proksch, V. Wray, L. Witte, J. Nat. Prod. 1997, 60, 716.

[13] C.-Y. Duh, S.-K. Wang, Y.-L. Weng, M. Y. Chiang, C.-F. Dai, J. Nat. Prod. 1999, 62, 1518.

[14] a) A. F. Ahmed, Y.-T. Hsieh, Z.-H. Wen, Y.-C. Wu, J.-H. Sheu, J. Nat. Prod. 2006, 69, 1275; b) S. C. Sinha, A. Ali, A. Bagchi, M. Sahai, A. B. Ray, Planta Med. 1987, 53, 55.

[15] E. Piers, R. W. Britton, W. de Waal, Can. J. Chem. 1969, 47, 831; G. G. Harrigan, A. Ahmad, N. Baj, T. E. Glass, A. A. L. Gunatilaka, D. G. I. Kingston, J. Nat. Prod. 1993, 56, 921.

[16] H.-J. Su, S.-H. Day, S.-Z. Yang, M. Y. Chiang, C.-N. Lin, J. Nat. Prod. 2002, 65, 79. 
[17] H.-J. Su, L.-W. Wang, C.-N. Lin, S.-H. Day, B.-L. Wei, S.-Z. Yang, S.-J. Won, Helv. Chim. Acta 2003, $86,2645$.

[18] I. Ohtani, T. Kusumi, Y. Kashman, H. Kakisawa, J. Am. Chem. Soc. 1991, 113, 4092

[19] A. H. Banskota, Y. Tezuka, K. Q. Tran, K. Tanaka, I. Saiki, S. Kadota, J. Nat. Prod. 2000, 63, 57.

[20] P. V. Demarco, E. Farkas, D. Doddrell, B. L. Mylari, E. Wenkert, J. Am. Chem. Soc. 1968, 90, 5480.

[21] D. Gaine, A. A. Boucugnani, W. R. Pennington, J. Org. Chem. 1976, 41, 3632.

[22] St. Melching, N. Bülow, K. Wihstutz, St. Jung, W. A. König, Phytochemistry 1997, 44, 1291.

[23] F. H. Allen, O. Kennard, J. Trotter, Acta Crystallogr., Sect. B 1973, 29, 1451.

[24] R.-S. Hou, C.-Y. Duh, M. Y. Chiang, C.-N. Lin, J. Nat. Prod. 1995, 58, 1126.

[25] F. M. Ho, C. C. Lai, L. J. Huang, T. C. Kuo, C. M. Chao, W. W. Lin, Br. J. Pharmacol. 2004, 141, 1037.

[26] E. K. Park, Y. W. Shin, H. U. Lee, S. S. Kim, Y. C. Lee, B. Y. Lee, D. H. Kim, Biol. Pharm. Bull. 2005, 28, 652.

[27] D. H. Lowry, N. J. Rosebrough, A. L. Farr, R. J. Randall, J. Biol. Chem. 1951, 193, 265. 